\title{
THE CHANGE OF RESIDENTS' ATTITUDES TOWARDS RENEWABLE ENERGY SOURCES IN 2006-2014 AS A REFLECTION OF PRIMARY RESEARCH
}

\author{
Domán Szilvia, ${ }^{1}$ Tamus Antalné, ${ }^{1}$ Erdélyi Tamás, ${ }^{* 1}$ Elena Horská2 \\ 1/ Károly Róbert College Gyöngyös, Hungary \\ ${ }^{2 / S}$ Slovak University of Agriculture in Nitra, Slovakia
}

\begin{abstract}
Within the frame of the North Hungarian region's eco-energy program, we examined the change of residents' attitudes to alternative energy sources during a multi-stage primary research. The level of familiarity and knowledge of the population, the examination of the source of knowledge and the analysis of renewable energy sources' judgment were the main areas of the standard interviews. According to our hypothesis, all of the information supply and attitudes related to the subject changed in a positive direction. The use of renewable energy sources is mainly dependent on the consumers' and residents' attitude in the given region. Consequently, we consider the knowledge of residents' attitude particularly important and that the multi-stage research was needed. Primary research was performed in form of standard interviews in households during 2006. Our research in 2009 and 2014 indicated the next phase, where we studied, how the relationship of the parties concerned to renewable energy sources has changed during the past three years.
\end{abstract}

Keywords: alternative energy resources, population survey, primary research

\section{Introduction}

The age of fossil fuels (coal, natural gas, and oil), lasting three hundred years, and the much longer historical period based on primary biomass (natural vegetation, primarily wood) burning are coming to an end. There are several reasons for this: quantitative limitations of energy sources and accelerated consumption of resources; accelerated growth of energy demand, low (but growing) effectiveness of current accession-procession and use of technologies to energy sources, in particular, the threatening pollution for quality of human life and the climatic balance overturn. (Green Tech, 2005)

According to several research groups' opinion, the latter processes have become irreversible, at most their deceleration, and, that is an important viewpoint; the reduction of economic-political risks (human and community victims, suffering) consequent on switchover for the period after the oil era can be possible. Our current era is called energy economy due to the central role of energy (Hahnel, 2010; Mészáros and Forgács, 2008; Smalley, 2003).

In case of Hungary - being a poor country both in traditional energy sources and equity - the strategic dependency on energy exporter is especially true. When we are talking about the upcoming end of the oil era, and its strategic risks, then the early development of domestic alternative energy industry must be placed in this strategic dimension among our proper time and adequate direction made steps (Dinya, 2009; Takács and Takács-György, 2013).

Most likely the switchover will indicate a transitional economic period, which has an unpredictable duration, in which at the beginning the renewable energy sources will be in minority, later through the gradual change of cost relations will increasingly forge ahead, while fossil fuels will be pushed into the background in a certain extent that allows their handling within natural and environmental limits.

The behavior of residents is related to the renewable energy sources affected by many factors (Dinya, 2008).

Firstly, the economically motivated behavior have to consider: in this regard the amount of expenses is a decisive factor, because a given person will choose an alternative energy source the release rate as a person, if he/she gets it cheaper. The perception of technology knowledge and its aspects (how reliable, comfortable, undisturbed) may affect its decision.

The human attitudes must also be taken into consideration. Natural uncertainty and resistance manifested towards all kinds of novelty, which is not necessarily about the specific product, but the 'novelty'. In many cases the lack of adequate information or even misinformation is responsible for this. The individual is able to make a decision in the knowledge of the benefits and disadvantages of the technology.

Also takes into account during the decision the given device's interference in its life. These can be annoying sound, light and odors, visual effects (chimneys, towers, glass surfaces, and drilling rigs), landscape destructive effects, increased proportion of built-up area, and the impact on the area's wildlife.

During the individual's opinion forming, he/she compares the factors created by him/her to the described benefits in the received knowledge.

Investments related to renewable energy sources are capital- and resource intensive, to its successful operation the consent of the members of the community may be essential. This can be realized if the community is aware of the benefits provided by the technology and also the disadvantages associated with it. This requires full scale information about the program's goals, advantages, and costs. In addition, adequate technical and financial background is needed and the local population should be interested financially in such a project realization to overcome any technical difficulties (Baros, 2012).

The investments should be realize as far as possible to all members of the community enjoy their advantages (Csete, 2008).

\section{The national and international tendencies in energy consumption}

Examining the domestic trends of the alternative energy sources use showed that in Hungary, the energy consumption per unit of GDP is sometimes two or two and a half times higher than in other European countries (Eurostat, 2013). 
In the European Union in 2004, the share of renewables within the total energy consumption was $5.7 \%$, the plan to 2012 is $12 \%$, according to the latest EU Commission survey, and there is a chance to cross the $10 \%$ threshold. Hungary undertook to 2010 to increase the renewable energy consumption rate to $3.6 \%$. Liquid fuels are available only for a few decades; this is suppose and require the renewal the $60 \%$ of Hungarian energy consumption.

Both in Hungary and internationally, many researchers studied the population and its relationship with environmental protection and eco-lifestyle (Palková et al., 2015). According to the joint survey by GfK and TÁRKI, only one third of the adult population is interested in the environment, and a similar proportion of them declares itself to be willing to do something to protect the environment (Consumers, 2009). Ipsos especially researched the youth opinion and stated that the environment protection is roughly equally important within young adults, and they are willing to take a bit more than average effort in order to protect the world around them (Ipsos, 2014).

Although energy is relatively expensive for the population, the results of OTP Building Savings Ltd. survey show that Hungarian families, unfortunately, are not energy conscious (Energy Site, 2012; HVG Online, 2012; Index, 2012), on the other hand, their attitudes to the changes are positive, which is anyway encouraging for behaviour change aimed programmes.

So far, very small percentage of households use alternative energy source in Hungary: the share of renewable energy in 2010 within the primary energy consumption was $7 \%$, while in the gross final energy consumption it was $8.7 \%$ (Eurostat, 2012; National Energy Strategy 2030, National Action Plan 2020) herewith the country significantly lagged behind the other EU member countries.

Solar power use appeared only at $0.1 \%$ of all households and the same number used pellets. The heat suppliers use approximately $9 \%$ of biomass-based fuels for thermal energy production (Tabi, 2011).

A number of secondary information related to energy use and energy awareness was available at the beginning of our research series, but we could not find relevant information regarding public attitudes towards renewable energies.

Our first research related to the topic was conducted in 2006, the second stint in 2009, third one was the 2014 survey.

\section{The aim and Methods of the Research}

Our research's aim is to define the most significant changes of our research series that spanned nearly through a decade, which occurred in the relationship to alternative energy sources among the population. The repeated survey provides an opportunity to see the market potential of alternative energy sources in process from the aspect of the population as one of the most significant target groups (Dinya et al., 2006).

We defined our research's focus how the interviewed ones' lives were concerned about the environment awareness, and what activities they are willing to do in order to protect their environment. The research showed that the level of knowledge related to the topic influence the environment attitude, this exploration influences the knowledge of renewable energy and associations related to the sample were studied. We also touched the issues related to alternative energies, and the expectations about their application as well (Domán et al., 2010).

Surveys were carried out with standard oral questioning among the population.

\section{Conditions for research}

During our researches the results of research, carried out mostly the same questionnaire, were compared in three different years. Survey research began in 2006 with a 598 inhabitants sample, and in 2009 we asked 806 people and 304 in 2014. Oral interview as the most effective research technique was applied during our primary research. (Malhotra, 2005).
Our sampling is not a representative one, arbitrary, in addition, we aspire that the sample showed more varied picture regarding the demographic characteristics.

\section{Results of the research}

During the research overview those results mentioned here that are based on same questions in all three questionnaires: associations related to energy resources, public expectations regarding their use, judgment of energy production facility's establishment and sources of energy carriers coming to their knowledge.

\section{Association regarding renewable energy sources}

Our associative study tends to know what concepts will be associated for the renewable energy sources by most of the respondents.

It is true for all three researches that the mention of environment is extremely high, followed by the cheapness, the local energy production, as well as investment demand's topics.

Compared to the results in 2006 (Figure 1), the three years later research shows that they more intensively associate to lack of political decisions.

Compared to our previous surveys, in 2014, the respondents are less occurred to cheap energy concerned to alternative energy sources.

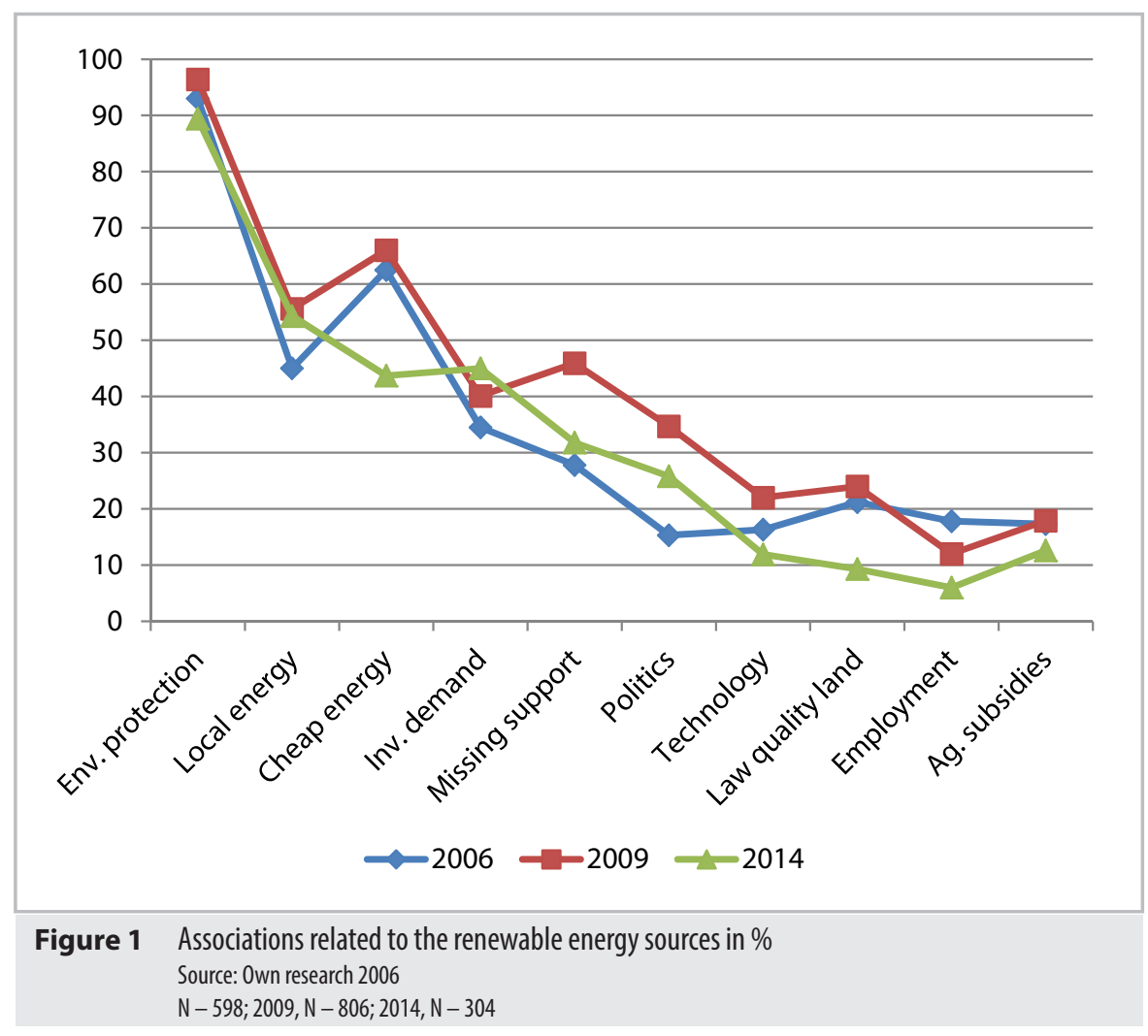

The Change of Residents' Attitudes Towards... $\square$ Domán, S., Antalné, T., Erdélyi, T., Horská, E. $\square$ vol. 4, 2015, no. $1 \square$ p. 17-21 
Table 1 Judgment of the renewable energy sources' future situation in \%

\begin{tabular}{|c|c|c|c|c|c|c|c|c|c|c|c|c|}
\hline & 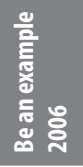 & 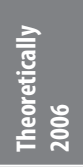 & 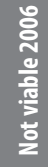 & $\begin{array}{l}\text { 흘 } \\
\text { 흥 융 }\end{array}$ & 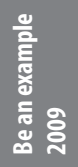 & 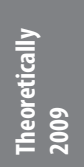 & 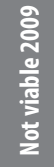 & $\begin{array}{l}\text { 흘 } \\
\text { 흥 용 }\end{array}$ & 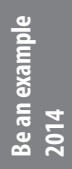 & 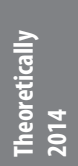 & 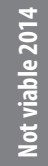 & 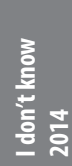 \\
\hline Biomass & 27.5 & 13.9 & 5.1 & 53 & 47.3 & 16.3 & 4.9 & 29.6 & 58 & 15.2 & 4.3 & 22.5 \\
\hline Biobriquet & 14.6 & 10.9 & 4.4 & 58.7 & 41.8 & 10.2 & 4.3 & 42.1 & 54.7 & 11.7 & 5.1 & 28.5 \\
\hline Biogas & 39.9 & 13.2 & 5.9 & 39.9 & 44.9 & 20.7 & 5.1 & 27.5 & 46 & 21.9 & 5.8 & 26.3 \\
\hline Biodiesel & 48.4 & 12.1 & 4.8 & 34.6 & 55.9 & 19.6 & 4.1 & 18.3 & 51.1 & 23.3 & 4.5 & 21.1 \\
\hline Bioethanol & 11.4 & 7.1 & 4.4 & 75.9 & 31.1 & 15.7 & 5.8 & 45.3 & 45.5 & 22.4 & 6 & 26.1 \\
\hline Energy forest & 11.4 & 8 & 11 & 68.8 & 14.2 & 14.3 & 13.5 & 55.7 & 14.7 & 29.4 & 7.4 & 48.5 \\
\hline Energy grass & 14.3 & 10 & 8 & 66 & 23.5 & 12.8 & 9.6 & 52.5 & 22.2 & 17 & 8.9 & 51.9 \\
\hline Geotherm & 30.7 & 13.6 & 7.6 & 47 & 57.7 & 11.4 & 5.4 & 23.7 & 58.1 & 13.2 & 5.1 & 23.5 \\
\hline Solar energy & 76.1 & 12.1 & 4.4 & 7.1 & 92.9 & 4.7 & 0.9 & 1 & 90.4 & 5.1 & 2.2 & 2.2 \\
\hline Wind energy & 76.2 & 10.2 & 5.3 & 8.1 & 86.3 & 8.9 & 2.6 & 1.6 & 83.8 & 12.5 & 0.7 & 2.9 \\
\hline Water energy & 73 & 11.7 & 5.4 & 9.3 & 75.5 & 12.3 & 6.7 & 4.7 & 80.9 & 13.2 & 2.9 & 2.9 \\
\hline Fotoelectric & 9.2 & 9 & 6.5 & 74.7 & 9.5 & 10.9 & 5.1 & 71.9 & 13.2 & 14.7 & 5.9 & 66.2 \\
\hline
\end{tabular}

Source: Own research 2006

$\mathrm{N}-598 ; 2009, \mathrm{~N}-806 ; 2014, \mathrm{~N}-304$

Both in 2006, 2009 and 2014, respondents seldom mentioned employment, utilization of poor quality lands, underdeveloped technology and the necessity of farmers' support in connection with the subject.

\section{Residents' expectations related to alternative energy source use}

The subject of our study was how the sample judges the possibilities of the future application of renewable energy sources in Hungary. More categories were set up for formulating of our judgment, depending on how they think the energy sources for the future are viable.

During comparing the results it can be clearly visible (Table 1), that the marking of the three bestknown sources of renewable energy is extremely high, such as solar energy, wind energy and water energy. The expectations are relatively positive related to the biomass, biodiesel and biobriquettes, about more than half of the respondents consider that it will be an example of their application.

Although, it can be seen in 2009 and then in 2014, that the residents are much more accepting related to the use of new types of energy, which can be attributed to the increase in their awareness. Particularly notable is the more positive judgment index of the biomass and biobriquettes, which doubled for 2014 and tripled compared to 2006.

During the survey our experience was that at this question the respondents who did not have adequate knowledge of the alternative energy source marked the 'do not know' category.

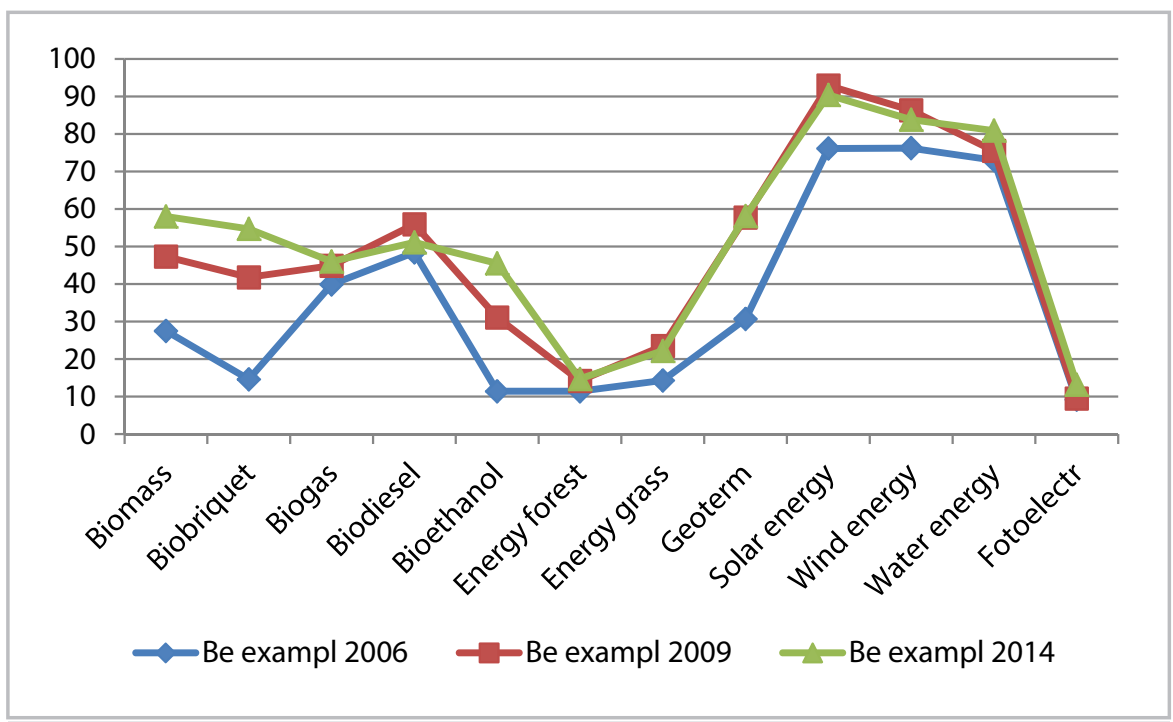

Figure 2 The changes of residents' expectations for domestic use: Will be an example for its application in \% Source: 0 wn research 2006

$\mathrm{N}-598 ; 2009, \mathrm{~N}-806 ; 2014, \mathrm{~N}-304$

Based on this, it can be stated that during the studied nine years, the respondents' knowledge level increased, because with the exception of the theoretically well-known solar-, wind- and hydro energy (which previously have been judged feasible) for all other energy sources is much less marked the 'do not know' response option (Figure 3).

\section{Respondents' attitude for the renewable energy production plant's establishment in their settlements}

Studying the possible support for a renewable energy plant establishment (Figure 4), that response option obtained conspicuous high values in all three years, that the respondent is only willing about this, if it has not financial implication onto him. On the positive side, nearly a quarter $(23.8 \%)$ of the respondents would support such an initiative in 2006, while in 2009 and 2014, this index has been close to $40 \%$. Regarding the financial support in 2014, a slight decline was experienced compared to previous years.

Just less than $5 \%$ of respondents are characterized by negative attitude to the theme in all three samples. 


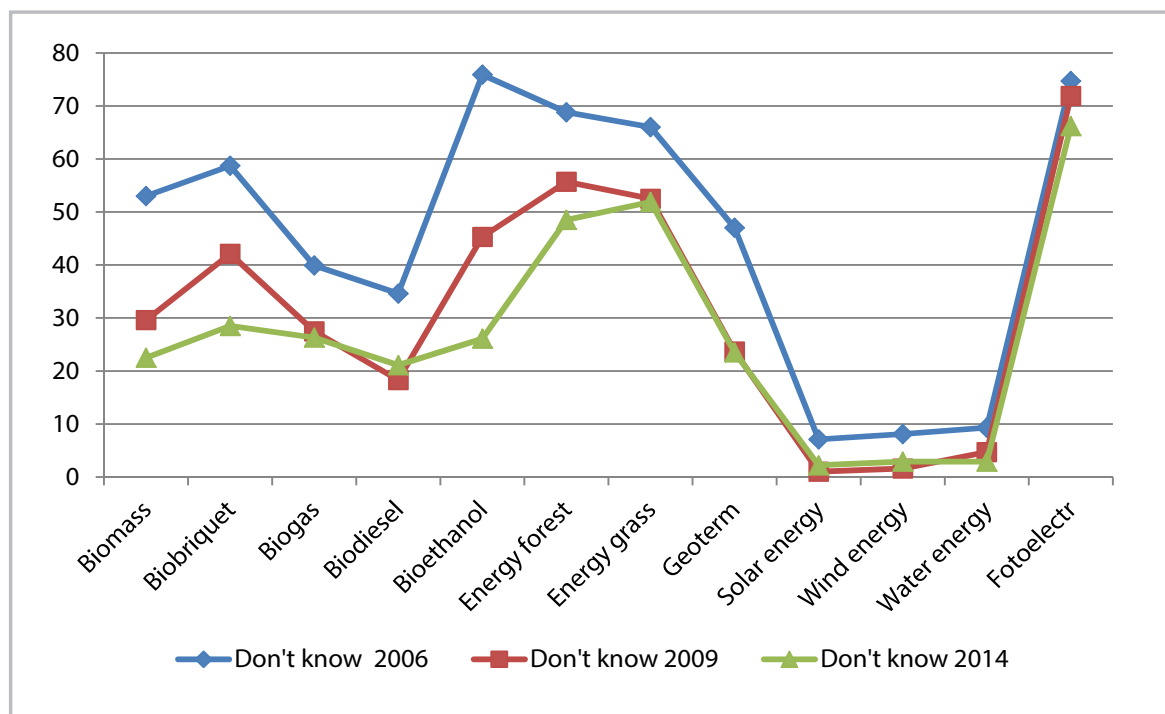

Figure 3 The changes of residents' expectations for domestic use: I don't know' category in \% Source: 0 wn research 2006

$\mathrm{N}-598 ; 2009, \mathrm{~N}-806 ; 2014, \mathrm{~N}-304$

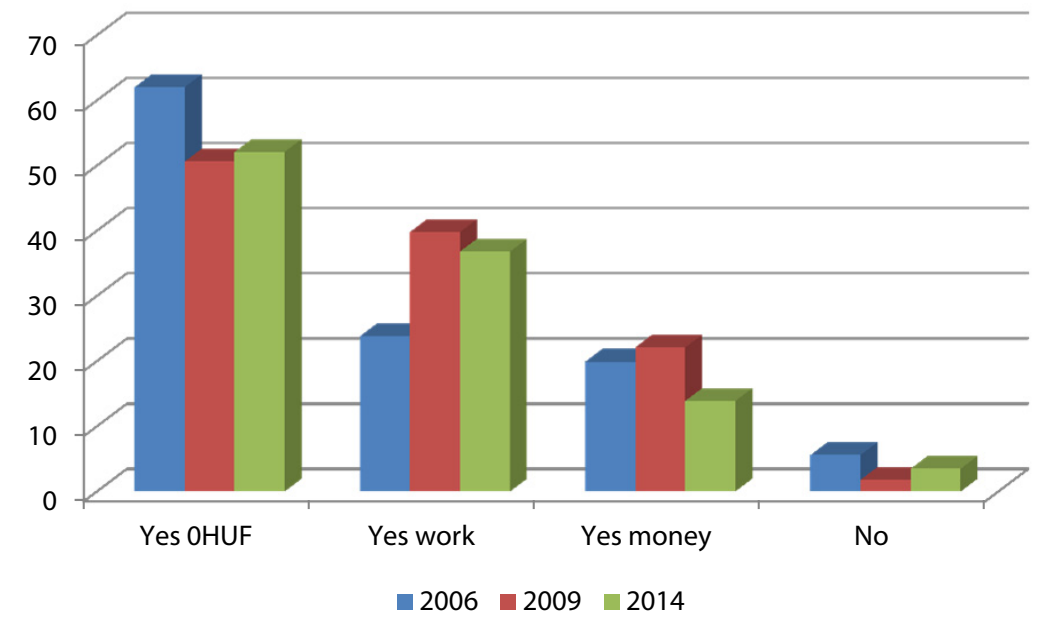

Figure 4 Support of plant's establishment on the settlement in \% Source: 0 wn research 2006

$\mathrm{N}-598 ; 2009, \mathrm{~N}-806 ; 2014, \mathrm{~N}-304$

Hyd. Power Plant Power Plant

Solar collector

Derrick

Solar panel

Wind farm

Wind turbine

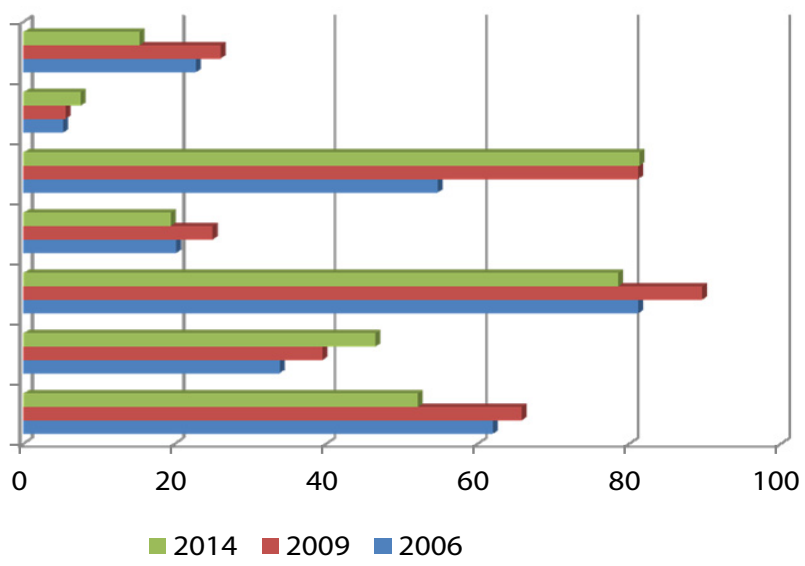

Figure 5 Acceptance willingness of plant's establishment in \%

Source: Own research 2006

$\mathrm{N}-598 ; 2009, \mathrm{~N}-806 ; 2014, \mathrm{~N}-304$

\section{Acceptance willingness of plant's \\ establishment that insure renewable energy operations}

Studying the individual motivations we asked that possibility how the population have an attitude the different facilities that would installed in their immediate environment (neighborhood, street, etc).

Very positive attitude among the respondents was demonstrated towards solar panels, solar collector, wind turbines and wind farm facilities. The judgment of solar collectors show a significantly positive picture in our last two surveys compared to the 2006 results (Figure 5).

The negative attitude did not change by 2014; it had been observed since 2006, that population would least accept the establishment of wood-fired thermal power plant (chimneys), the rig and a hydroelectric power plant. Only 5.3\% of respondents show willingness for this.

\section{Source of knowledge obtainment for energy carriers}

Studying the obtained knowledge of energy sources showed that while in 2006 and 2009, the sample's actors typically favoured the traditional media such as television, newspapers and radio (Figure 6), this trend significantly changed by 2014. TV, radio and the printed media's role significantly decreased, while the Internet has been increasingly gaining ground in terms of knowledge sources. The reference groups' fulfilled role decreased as a source of information by 2014 .

\section{Conclusion}

The purpose of the research series was the exploration of inhabitants' awareness related to renewable energy resources and understanding the overall environmental attitudes of Hungarian population.

The results show that after nearly a decade, the solar, wind and hydro energy is regarded as the best known within the test samples in the future too. During in reference to the term of alternative energy the respondents primarily associate to the environment, but its cheapness and high investment costs are also floating in front of their eyes.

Assessment of renewable energies' future status shows that the resident expectations are mostly positive in relation to the three best-known sources of energy; on the other hand, judgment of biomass, biobriquettes and biodiesel, and the prognosis for their spread for 2014 has improved a lot, which is presumably also due to rising awareness about them. 


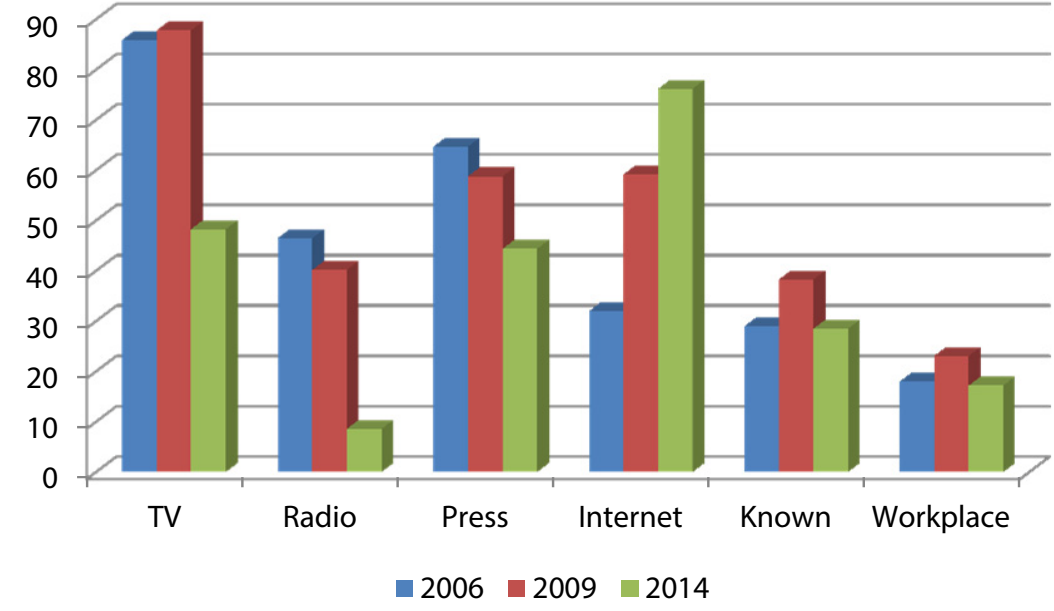

Figure 6 Source of knowledge obtainment Source: Own research 2006 $\mathrm{N}-598 ; 2009, \mathrm{~N}-806 ; 2014, \mathrm{~N}-304$

A significant percentage of respondents would positively receive the presence and use of renewable energy technology in the immediate vicinity. In particular, the solar and wind energy utilization have a high social acceptance, more than $80 \%$ of respondents would agree with solar collectors, solar panels, and nearly two-thirds with windmills near their residences.

However, the obtained knowledge of the energy sources compared with the previous indicates a change: the traditional media are pushed into the background, the role of the Internet within getting information has increased significantly.

Our hypothesis was confirmed, that in the examined period, the level of population's knowledge regarding the alternative energy sources has increased and their attitudes became more favourable.

The source of obtained knowledge of energy carriers compared to the previous ones also shows a change: the traditional media are pushed into the background, the role of the Internet has increased significantly within getting information.

\section{Acknowledgment}

This paper was co-funded by the European Community under the project no 26220220180: Building Research Centre „AgroBioTech".

\section{References}

BAROS, Z. 2012. Climate change, climate protection, climate policy Károly Róbert College books of TÁMOP-4.1.2 A1 and TÁMOP-4.1.2 A2

CONSUMERS. 2009. http://www.fogyasztok.hu/ cikk/20090616/gfk_hungaria_es_taki_magyarok_ harmadat_erdekli_a_kornyezetvedelem June 2009. Download: 2015.01.09.

CSETE, L. 2008. New paradigm in the agriculture: adjustment to new global challenges. In Gazdálkodás, vol. 52, 2008, no., 4, pp. 352-367.

DINYA, L. 2008. Sustainability challenges and biomassbased energy production. In Gazdálkodás, vol. 53, 2008, no. 4, pp. 310-324.

DINYA, L. 2009. Overview of the status of biomassbased energy production situation (study, MTAEnvironmental Science Presidential Committee 'Energy and Environment' Subcommittee, Budapest, MTA, 2009.

DINYA, L. - DOMÁN, SZ. - FODOR, M. - TAMUS, A-né. 2006. Residents' opinion of alternative energy sources. vol. 40, 2006, no. 4, pp. 49-55. INDEX 25545 HU ISSN 1219-03-49.

DOMÁN, SZ. - FODOR, M. - TAMUS, A-né. 2010. Changes in residents' opinion of alternative energy sources. In Gazdálkodás, 2010, no. 1, pp. 92-97. ISSN 00465518.

ENERGY SITE. 2012: http://energiaoldal.hu/pazarnem-energiatudatosak-a-magyar-csaladok/ 2012. szeptember. Download: 2015. 02. 10.

GREENTECH. 2005. MAVIR: The wind industry has to make the network flexible September 2005. http:// zoldtech.hu/cikkek/20050921mavir. Download: 2012. 03. 19.

HAHNEL, R. 2010. Green Economics: Confronting the Ecological Crisis. New York: M. E. Sharpe, 2010. 280 p.
HVG Online. 2012. http://hvg.hu/ingatlan/20120919 Nem_figyelik_ energiafogyasztasukat_a_magy September 2012. (download: 2015. 02. 10.)

INDEX. 2012. http://index.hu/gazdasag/ magyar/2012/08/30/felmilliot_koltunk_ rezsire_ evente/ August 2012. Download: 2015.02. 10.

IPSOS. 2014. http://ipsos.hu/hu/news/tesznek-ertevagy-futyulnek-ra, February 2014. Download 2014. 02.09.

MALHOTRA, N. K. 2005. Marketing research. Akadémiai Kiadó, 2005. 905 p. ISBN 9630583070.

MÉSZÁROS, S. - FORGÁCS, Cs. 2008. Agriculture researches on new ways. In Gazdálkodás, vol. 52, 2008, no. 4, pp. 334-351.

MINISTRY OF NATIONAL MINISTRY. 2012. National energy strategy 2030. February 2012. http://www. kormany.hu/download/4/f8/70000/Nemzeti\%20 Energiastrat\%C3 \%A9gia \%202030\%20teljes\%20 v\%C3\%A1ltozat.pdf. Download: 2015. 02. 08.

II. NATIONAL ENERGY EFFICIENCY ACTION PLAN. 2016. (w.y.) www.nih.gov.hu/strategiaalkotas/energetika/ hu-energy-efficiency. Download: 2015. 01. 17.

PALKOVÁ, Z. - HORSKÁ, E. - GADUŠ, J. - MASSARI, S. F. DOMÁN, SZ. - TAKÁCS-GYÖRGY, K. 2015. Renewable Energy in Europe: Through the Policy, Education and People. Gödöllő : St. Stephen University, 2015. 166 p. ISBN 978-963-269-466-5.

SMALLEY, R. E. 2003. Top Ten Problems of Humanity for Next 50 Years. Energy \& Nano Technology Conference, Rice University, May 3, 2003. 16. p.

TABI, A. 2011. Analysis of the Hungarian households' energy footprint based on resident survey. In Csutora M. (ed.): The economy of ecological footprint. Aula Kiadó, Budapest, 2011. pp. 77-90.

TABI, A. 2013. Renewable energy survey 2013. Analysis of the social acceptances of renewable energy technologies http://korny.uni-corvinus.hu/kutatas/ me gujulo_felmeres_ 2013.pdf. Download: 2015. 02.02.

TAKÁCS, I. - TAKÁCS-GYÖRGY. K. 2013. Arguments for the optimisation of using biomass for energy production. Applied Studies in Agribusiness and Commerce 72-3, 2013. pp. 103-108.

\section{Contact address}

*Dr. Erdélyi Tamás, Károly Róbert College Gyöngyös, Hungary e-mail: terdelyi@karolyrobert.hu 